\title{
Monomethyl Suberate Screening for Antifungal Activity, Molecular Docking and Drug-Like Properties
}

\section{Lyudmyla Antypenko, ${ }^{\star}$ Fatuma Meyer, Zhanar Sadykova, Leif-Alexander Garbe and Karl Steffens}

\author{
Faculty of Agriculture and Food Science, Neubrandenburg University Brodaer Str. 2, 17033, Neubrandenburg, Germany \\ * Corresponding author: E-mail: antypenkol@gmail.com
}

Received: 03-05-2018

\begin{abstract}
Antifungal activity of suberic acid monomethyl ester (monomethyl suberate) was investigated in a growth inhibition assay comprising of 11 different fungi and 3 Phytophthora oomycetes strains relevant in agriculture. In comparison to standard antifungal hymexazol, monomethyl suberate showed moderate antifungal effects at a concentration range of $100-300 \mu \mathrm{g} / \mathrm{mL}$. Alternaria alternata, Fusarium equiseti, Fusarium fujikuroi and Phytophtora infestans GL-1 were the most sensitive fungi showing inhibition rates up to $100 \%$. Physico-chemical descriptors of monomethyl suberate revealed its low toxicity profile. Molecular docking analysis comprising several known antifungal targets points to the $\mathrm{N}$-myristoyltransferase as the most probable site of interaction.
\end{abstract}

Keywords: Monomethyl suberate; antifungal activity; molecular docking; drug-like descriptors

\section{Introduction}

In continuation of our search for highly effective natural antifungal agents among trihydroxy fatty acids with low toxicity, the starting reagent in synthesis of pinnelic acid (9,12,13-trihydroxy-10-octadecenoic acid), ${ }^{1}$ namely, suberic acid (octanedioic acid) (Figure 1) attracted our interest.<smiles>O=C(O)CCCCCCC(=O)O</smiles>

Figure 1. Chemical stucture of suberic acid.

Suberic acid is known to be obtained along with azelaic acid through oxidation of ricinoleic $\mathrm{acid}^{2}$ or as a component isolated from oil extracted from Vernonia galamensis. ${ }^{3}$ Antonova et al. described its synthesis by oxidation of cyclooctane-1,2-diol. ${ }^{4}$ Suberic acid (4.13\%) and its monomethyl ester (2.38\%) were also detected by gas chromatography-mass spectrometry (GC-MS) in methanolic extracts of Hibiscus micranthus stem along with 56 other compounds. ${ }^{5}$ Furthermore, monomethyl suberate was found by GC-MS in an ethylacetate/hexane extract of Pestalotiopsis JCM2A4, an endophyte growing on Chinese mangrove plant Rhizophora mucronata. ${ }^{6}$
To our knowledge, reports on physiological role(s) and potential biotechnological application(s) of suberic acid or its derivatives are scarce. Staphylococcus aureus and Candida albicans were shown to be sensitive to a chloroform extract of Polysiphonia denudate $f$. fragilis (Rhodophyceae), which contained suberic acid dimethyl ester $(0.2 \%)$ among other biologically active substances. ${ }^{7}$ The latter was also detected by GC-MS in the larval and pupal internal lipids of medically important flies Calliphora vici$n a(0.15-0.20 \mu \mathrm{g} / \mathrm{g})$ and Sarcophaga carnaria (0.14-0.21 $\mu \mathrm{g} / \mathrm{g}){ }^{8}$ In the same study it was shown, that the substance itself slightly inhibited the growth of entomopathogenic fungi of Beauveria bassiana (Dv-1/07), B. bassiana (Tve-N39), Lecanicillium lecanii, Metarhizium anisopliae, Paecilomyces fumosoroseus and Paecilomyces lilacinus with a minimal inhibitory concentration (MIC) of $512 \mu \mathrm{g} / \mathrm{mL}$. Antimicrobial tests carried out with diverse gram-positive and gram-negative bacterial strains, as well as with the fungi Candida albicans and Candida tropicalis, were without any positive results. ${ }^{8}$

Recently, Iornumbe et al. ${ }^{9}$ investigated the antifungal activity of suberic acid organotin derivatives against $M i-$ crosporum gypseum, M. audounii, M. distortum, M. gallinae and Trichoephyton: mentagrophytes and T. equinum. They found a decreasing average activity according to diverse octandioate rests: potassium triphenyltin(IV) oc- 
tanedioate $>$ potassium tributyltin(IV) octanedioate $>$ potassium dibutyltin(IV) octanedioate $>$ potassium diphenyltin(IV) octanedioate. The activities were comparable to standard antifungals fulcin and fluconazole. The leading compounds MICs were found to be $25 \mu \mathrm{g} / \mathrm{mL}$. The free suberic acid or its monopotassium salt exhibited a weaker antifungal activity than synthesized organotin compounds, inhibiting growth of only $M$. distortum and $T$. equinum. This fits to the observation that many biologically compounds enhance their activity upon complexation. ${ }^{10}$

Only few suberic acid derivatives were reported to have non-pharmacological applications: octacalcium phosphate carboxylates as bone reconstructors for biomedical applications; ${ }^{11}$ suberate as thermotropic liquid crystalline polymers; ${ }^{12}$ poly(propylene suberate)s ${ }^{13}$ and poly(butylene suberate) $\mathrm{s}^{14,15}$ as biodegradable polyesters for sutures, implant materials for tissue engineering, and biologically active controlled drug-release devices; anhydrous copper suberates as polymers with extended bridged structures, which are interesting materials to study spin exchange and charge transfer between metal ions. ${ }^{16}$ Interestingly, in a very different context suberic bishydroxamate was found to be a potent agent in overcoming resistance of melanoma to "TNF-related apoptosis-inducing ligand", which induces apoptosis by acting as a histone deacetylase inhibitor. ${ }^{17}$

Here we present an investigation of antifungal activity of monomethyl suberate.

\section{Results and Discussion}

\section{1. Antifungal Activity}

We decided to work on monomethyl suberate, because dimethyl ester was already described having only a moderate antifungal activity $(512 \mu \mathrm{g} / \mathrm{mL} \mathrm{MIC}) .{ }^{8}$ Furthermore, the monoethyl ester of azelaic acid, which bears a molecular scaffold structure very similar to suberate, showed a pronounced antifungal activity against Pyricularia oryzae with an $\mathrm{MIC}_{50}$ of $50 \mu \mathrm{g} / \mathrm{mL}$ (free acid: $\mathrm{MIC}_{50}$ at $95 \mu \mathrm{g} / \mathrm{mL}) .{ }^{18,19}$ This observation is probably due to higher lipophilicity of the monoethyl ester form..$^{20}$ Thus, antifungal studies of shorter in one carbon dicarboxylic acid, namely, suberic, seemed promising with enhancing its lipophilicity in monomethyl ester form.

Eleven fungi and three Phytophtora strains were probed with methyl suberate at 50, 100 and $300 \mu \mathrm{g} / \mathrm{mL}$. Hymexazol $(50 \mu \mathrm{g} / \mathrm{mL})$ was included used as standard antifungal. The findings are summarized in Figure 2. At the lowest concentration $(50 \mu \mathrm{g} / \mathrm{mL})$ four strains showed a moderate sensitivity to monomethyl suberate: Altenaria alternata (21.3\%), Phytophtora infestans GL-1 (16.3\%), Fusarium oxysporum (13.1\%) and F. equiseti (12.8\%). At this concentration hymexazol was effective against each strain with a higher inhibition activity (17-100\%) than monomethyl suberate.
At $100 \mu \mathrm{g} / \mathrm{mL}$ P. infestans $G L-1$ was the most sensitive strain showing $100 \%$ of inhibition. A nearly $50 \%$ inhibition was observed to Altenaria alternata and $F$. equiseti. Only moderate effects were detected against $P$. infestans p-3 (4/91; R+) and F. fujikuroi, with approximately $27 \%$ of inhibition. Antifungal activities were even lower against $P$. infestans p-4 (4/91; R-) (18.5\%), F. oxysporum (16.2\%), Verticillium lecanii (13.3\%), Colletotrichum higginsianum (8.0\%) and F. graminearum (7.4\%). Aspergillus niger, Botrytis cinerea, Mucor indicus and Penicillium digitatum were completely insensitive to the monomethyl suberate at the studied concentration. At a concentration of $300 \mu \mathrm{g} /$ $\mathrm{mL}$ only two fungi remained resistant: $M$. indicus and $P$. digitatum. Interestingly, against $A$. alternata and $F$. equiset $i$ the antifungal effect remained practically unchanged (54$60 \%$ of growth inhibition). Antifungal activity against all other fungi became stronger with elevated concentrations. The most sensitive strain was F. fujikuroi (72.9\%). Fungi $F$. oxysporum, F. graminearum, Verticillium lecanii, and strains p-3 (4/91; R+) and p-4 (4/91; R-) of $P$. infestans were only moderately inhibited (40-56\%). Lower inhibition effects were found against C. higginsianum (33.5\%), Botrytis cinerea (16.2\%), and Aspergillus niger (16.2\%).

\section{2. Drug-Likeness Physico-Chemical Parameters and Promiscuity Score}

Considering the found moderate antifungal activity of monomethyl suberate at $300 \mu \mathrm{g} / \mathrm{mL}$, its physico-chemical parameters were calculated by Molinspiration engine ${ }^{21}$ (Table 1) in order to predict the level of drug-likeness, toxicity $^{22-24}$ and substance promiscuity. ${ }^{25}$ These properties may be of value if monomethyl suberate will be considered as a compound in human medical care, food processing or as an antifungal in agriculture. For comparison, corresponding data for the standard antifungal hymexazol are also shown (CHEMBL244877). ${ }^{26}$

As it is seen from the Table 1, monomethyl suberate complies to all presented criteria for molecular properties, that influence the oral bioavailability of drug candidates, ${ }^{22-24}$ except of molecular polar surface area (TPSA). Its surface is larger $\left(63.30 \AA^{2}\right)$ than that of hymexazol $\left(42.26 \AA^{2}\right)$, which implies its penetration of the blood brain barrier is less likely. Calculating the promiscuity of biological activity of monomethyl suberate with "bioactivity data associative promiscuity pattern learning engine" (Badapple), ${ }^{25}$ no data were found in the database, which means a neutral result with respect to toxicity prediction. At least the predicted promiscuity was not found to be high. For hymexazol the pScore was shown with a moderate true value (238) based on reported biological activity data of drugs with isoxazole scaffold. So, the reference antifungal hymexazol demonstrated higher level of potentially binding to a variety of bimolecular targets, and thereby may have higher level of toxicity than tested natural monomethyl suberate. ${ }^{27}$ 


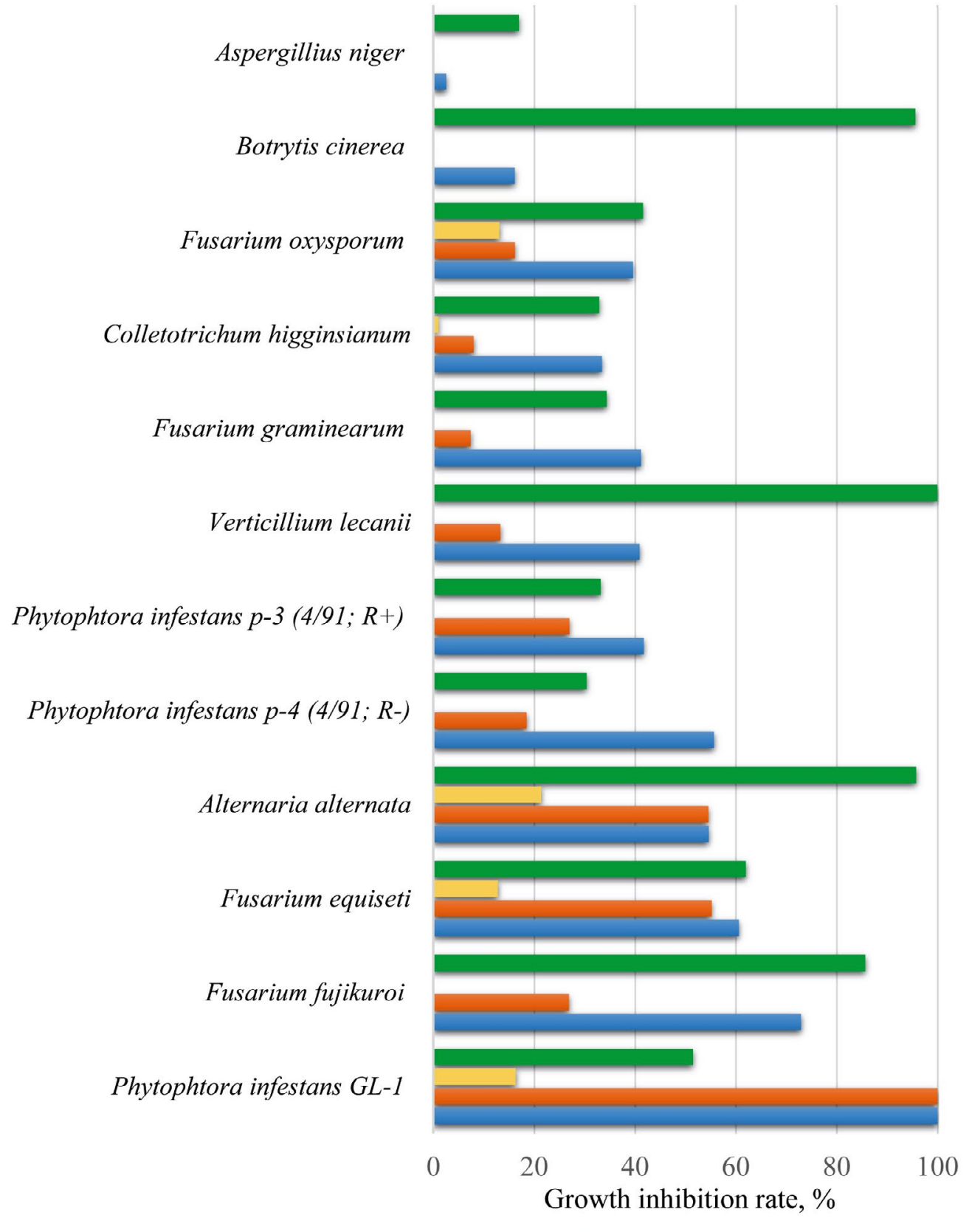

Figure 2. Growth inhibition of studied fungal strains by hymexazol (hym) in $50 \mu \mathrm{g} / \mathrm{mL}$ and monomethyl suberate (ms) in $50,100 \mathrm{and} 300 \mu \mathrm{g} / \mathrm{mL}$. Mucor indicus and Penicillium digitatum were insensitive in all tests.

Table 1. Calculated parameters of lead-like \& structure optimization and promiscuity scores

\begin{tabular}{|c|c|c|c|c|c|c|c|}
\hline Substance / SMILES & $\mathbf{M W}^{*}$ & $\log P$ & TPSA & nrotb & HBA & HBD & pScore \\
\hline \multicolumn{8}{|l|}{ Monomethyl suberate } \\
\hline $\operatorname{coc}(=\mathrm{O}) \operatorname{cccccc}(\mathrm{O})=\mathrm{O}$ & 188.2 & 1.67 & 63.30 & 8 & 4 & 1 & no data \\
\hline \multicolumn{8}{|l|}{ Hymexazol } \\
\hline $\mathrm{CC} 1=\mathrm{CC}(=\mathrm{NO} 1) \mathrm{O}$ & 99.1 & 0.73 & 42.26 & 0 & 2 & 1 & 238 \\
\hline Drug lead-like criteria & $\leq 500$ & $\geq-0.5 \leq 5$ & $\geq 75 \leq 140$ & $\leq 10$ & $\leq 10$ & $\leq 5$ & - \\
\hline
\end{tabular}

${ }^{\star} \mathrm{MW}$ - molecular weight; $\log \mathrm{P}$ - octanol/water partition coefficient; TPSA - molecular polar surface area; nrotb - number of rotatable bonds; HBA - hydrogen bonds acceptors; HBD - hydrogen bonds donors; pScore - promiscuity score. 


\section{3. Molecular Docking}

A literature survey did not give us any indication with respect to a biological target, to which monomethyl suberate may bind and thereby reveal a mode of action of growth inhibition. Only PubChem BioAssays (CHEMBL1162491 $)^{26}$ reported suberic acid to be an antagonist of the retinoid-related orphan receptor gamma, farnesoid-X-receptor, thyroid hormone receptor beta and NFkB signaling pathways. All these reports are related to human health studies. So, investigations to elucidate antifungal mechanism(s) of suberate's with respect to fungi of agricultural importance are worth to study.

Analysis of in silico molecular docking predicted affinity scores ${ }^{28}$ to six common fungal targets (enzymes) ${ }^{29}$ and showed, that monomethyl suberate may interact with them with higher probability, than hymexazol (Table 2).

The highest affinity score (-6.0) of monomethyl suberate was calculated to $\mathrm{N}$-myristoyltransferase (NMT). In
Figure 3 it is shown how it fits into the active site of this enzyme.

Two conventional hydrogen bonds are formed with HIS B:227 (3.05 $\AA$ ) and ASN B:392 (3.04 $\AA$ ) due to carbonyl oxygen in methyl ester residue of suberate. A further hydrophobic Pi-sigma bond build up between PHE B:240 $\left(3.76 \AA\right.$ ) and $\mathrm{MeC}(\mathrm{O}) \underline{\mathrm{CH}}_{2}$ fragment. Thus, $\mathrm{N}$-myristoyltransferase (NMT) should be among priority antifungal targets for further in vitro enzymatic studies.

\section{Experimental}

\section{1. Antifungal Studies}

The mycelial growth rate assay was used for antifungal studies. ${ }^{30}$ Strains of filamentous fungi were obtained from the following sources: Asperillus niger DSM 246, Altenaria alternata DSM 1102, Fusarium equiseti DSM 21725,

Table 2. Calculated affinities of monomethyl suberate and reference hymexazol to common antifungal enzymatic targets, $\mathrm{Kcal} / \mathrm{Mol}$

\begin{tabular}{lccc}
\hline Target enzyme & $\begin{array}{c}\text { PDB } \\
\text { code }\end{array}$ & $\begin{array}{c}\text { Affinity for } \\
\text { monomethyl suberate }\end{array}$ & $\begin{array}{c}\text { Affinity } \\
\text { for hymexazol }\end{array}$ \\
\hline $\boldsymbol{N}$-Myristoyltransferase (NMT) & $1 \mathrm{IYL}$ & -6.0 & -4.9 \\
Topoisomerase II (Topo II) & $1 \mathrm{Q} 1 \mathrm{D}$ & -5.5 & -4.7 \\
$\begin{array}{l}\text { Sterol 14a-demethylase (CYP51) } \\
\text { UDP- } \boldsymbol{N} \text {-acetyl-muramoyl- } \boldsymbol{L} \text {-alanine: }\end{array}$ & $5 \mathrm{TZ1}$ & -5.3 & -4.3 \\
$\begin{array}{l}\boldsymbol{D} \text {-glutamate ligase (MurD) } \\
\text { Secreted aspartic proteinase (SAP2) }\end{array}$ & $1 \mathrm{UAG}$ & -5.1 & -4.4 \\
$\begin{array}{l}\boldsymbol{L} \text {-Glutamine: } \boldsymbol{D} \text {-fructose-6-phosphate } \\
\text { aminotransferase (GlcN-6-P) }\end{array}$ & $1 \mathrm{EAG}$ & -4.8 & -3.9 \\
\hline
\end{tabular}

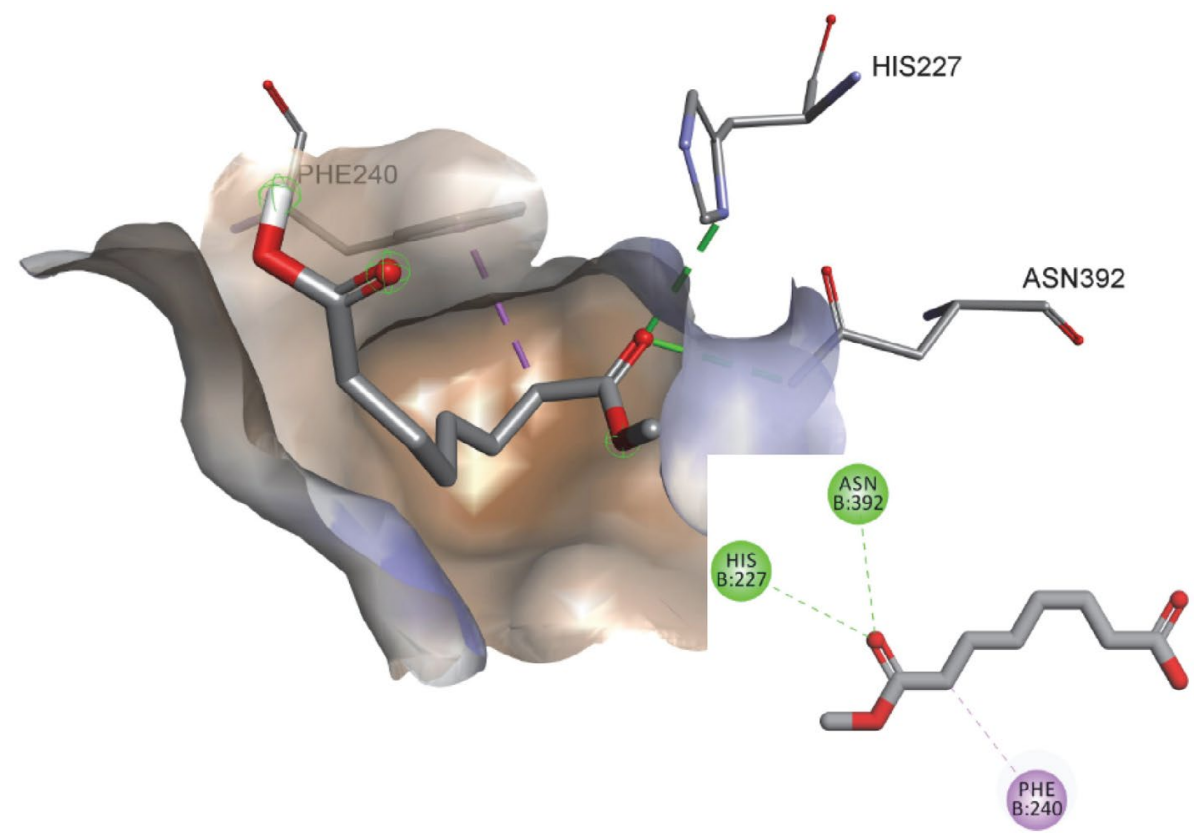

Figure 3. Visual representation (3D and 2D) of the monomethyl suberate showing bonds formation and position in the active site of $N$-myristoyltransferase (NMT) of Candida albicans. ${ }^{29}$ 
F. graminearum DSM 1095, F. fujikuroi DSM 893, Verticillium lecanii, Mucor indicus DSM 2185, Penicillium digitatum DSM 2731 from DSMZ (Braunschweig, Germany); Fusarium oxysporum 39/1201 St. 9336 and Botrytis cinerea from the Technische Universität Berlin (Germany); Colletotrichum higginsianum MAFF 305635, originally isolated in Japan, via the Department of Biology, Friedrich-Alexander-Universität (Erlangen, Germany); oomycetes Phytophtora infestans GL-1 01/14 wild strain, p-3 (4/91; R+) and p-4 (4/91; R-) strains were kindly donated by Julius Kühn-Institut (Quedlinburg, Germany). Potato Dextrose Agar (PDA) were purchased from C. Roth (Karlsruhe, Germany). Hymexazol (98\%) was obtained from Prosperity World Store (Hebei, China). Monomethyl suberate (97\%) was purchased from Jinan Yudong Trading Co., Ltd. (Jinan, China). Strains were cultivated on PDA for $6 \mathrm{~d}$ at $25^{\circ} \mathrm{C}$. Spores from each strain were gently harvested with a sterile glass rod from plate surfaces with deionized water. Spore concentration numbers in suspension were determined microscopically and adjusted to $7.5^{\star} 10^{6} \mathrm{spores} / \mathrm{mL}$. A clear stock solution of $5 \mathrm{mg} / \mathrm{mL}$ was made of $0.050 \mathrm{~g}$ of reference substance hymexazol in $10 \mathrm{~mL}$ of deionized sterile water as solvent. $1 \mathrm{ml}$ of each stock solution was mixed in situ into $99 \mathrm{ml}$ of PDA prior to solidification to obtain a final concentration of $50 \mu \mathrm{g} / \mathrm{mL}$. In the same way mixtures of PDA with monomethyl suberate were prepared with final concentrations of 50,100 and $300 \mu \mathrm{g} / \mathrm{mL} .9 \mathrm{~mL}$ of each mixture were poured into $6 \mathrm{~cm}$ diameter petri dishes. After solidification central hole (diameter: $2.5 \mathrm{~mm}$ ) was cut out and inoculated with $6.5 \mu \mathrm{L}$ spore suspension. Plates were incubated at $25^{\circ} \mathrm{C}\left(+/-1{ }^{\circ} \mathrm{C}\right)$ for $6 \mathrm{~d}$. Control plates containing only PDA and water were prepared in the same way. Inhibitory effects (I \%) were determined by analyzing growth zone diameters and calculated as described by Tang et al.:

$$
\mathrm{I} \%=[(\mathrm{C}-\mathrm{T}) /(\mathrm{C}-2.5 \mathrm{~mm})])^{\star} 100,
$$

where $\mathrm{C}(\mathrm{mm})$ represents the growth zone of control PDA, and $\mathrm{T}(\mathrm{mm})$ the average growth zone in presence of methyl suberate..$^{30}$ All growth experiments were carried out in triplicate. Means and standard deviations were calculated with software "Exel 2016" (Microsoft, USA).

\section{2. Molecular Docking}

Macromolecular data was downloaded from the Protein Data Bank (PDB), ${ }^{31}$ namely, the crystal structures of sterol 14a-demethylase (CYP51) 5TZ1, topoisomerase II (Topo II) 1Q1D, L-glutamine: D-fructose-6-phosphate amidotransferase (GlcN-6-P) 1XFF, secreted aspartic proteinase (SAP2) 1EAG, N-myristoyltransferase (NMT) 1IYL, and UDP-N-acetylmuramoyl-L-alanine: D-glutamate ligase (MurD) 1UAG. As reference hymexazol (3-hydroxy-5-methylisoxazole) was chosen according to reported antifungal analysis. ${ }^{30}$
Ligand preparation. Substances were drawn using MarvinSketch 6.3.0 and were saved in mol format. ${ }^{32}$ Afterwards they were optimized by program Chem3D using molecular dynamics MM2 algorithm and saved as pdbfiles. Molecular mechanics was used to produce more realistic geometry values for the majority of organic molecules owing to the fact of being highly parameterized. By using AutoDockTools-1.5.6 pdb-files were converted to PDBQT, and number of active torsions was set as default. ${ }^{28}$

Protein preparation. PDB files were downloaded from the protein data bank. ${ }^{31}$ Discovery Studio 4.0 was used to delete water molecules and ligand from the crystal. The proteins were saved as pdb-files. In AutoDockTools-1.5.6 polar hydrogens were added and saved as PDBQT. Grid box was set as following: center_ $\mathrm{x}=70.728$, center_y $=65.553$, center_ $z=3.865$, size $\_x=20$, size $\_y=20$, size $\_z=20$. Vina was used to carry out docking. For visualization Discovery Studio Visualizer v17.2.0.16349 was applied. ${ }^{33}$

\section{Conclusion}

The antifungal spectrum of monomethyl suberate was investigated against 11 different fungi and 3 Phytophthora oomycetes strains of agricultural importance. The monomethyl ester derivative revealed a significantly higher activity than the dimethyl ester ${ }^{8}$, but an average lower activity than reference antifungal hymexazol. Nevertheless, an extraordinary activity was observed against strain GL-1 of the devastating oomycete $P$. infestans. Furthermore, monomethyl suberate as a naturally occurring substance has a more environmentally friendly structure with less promiscuity score than conventional antifungals with heterocyclic ring systems. Therefore, we expect to have at hand an antifungal drug with an attractive profile with respect to potential toxicity and mutagenicity.

\section{Acknowledgements}

Authors gratefully acknowledge German Federal Ministry of Education and Research (Grant: FKZ 03FH025IX4) for financial support of this work; Federal Research Centre for Cultivated Plants (Quedlinburg, Germany) for presenting the strain Phytophthora infestans; Department of Biology, Friedrich Alexander University, Erlangen, Nürnberg, Germany for the strain Colletotricum higginsianum, and Dr. Oleksii Antypenko (Zaporizhzhya State Medical University, Ukraine) for conducting molecular docking.

\section{References}

1. T. Shirahata, T. Sunazuka T, K. Yoshida, S. Omura, Tetrahedron Org. Chem. Ser. 2006, 62, 9483-9496.

DOI:10.1016/j.tet.2006.06.088 
2. P. E. Verkade, Recueil des Travaux Chimiques des PaBas 1927, 46, 137-143. DOI:10.1002/recl.19270460209

3. F. O. Ayorinde, G. Osman, R. L. Shepard, F. T. Powers, J. Am. Oil Chem. Soc. 1988, 65, 1774-1777.

DOI:10.1007/BF02542380

4. T. N. Antonova, S. A. Mashina, A. A Kunitskii, N. V. Artem'eva, Khim. Khim. Tekhnol. 2003, 46, 114-116.

5. K. Ashok, S. R. Setty, L. Narsu, Pharmacogn. J. 2010, 2, 21-30. DOI:10.1016/S0975-3575(10)80074-4

6. L. Liu, X. Lu, Plast. Rubber Compos. 2002, 31, 283-288. DOI:10.1179/146580102225005009

7. S. De Rosa, Z. Kamenarska, V. Bankova, K. Stefanov, S. Dimitrova-konaklieva, H, Najdenski, I. Trevtkova, S. Popov, Zeitschrift fur Naturforsch - Sect. C. J. Biosci. 2001, 56, 10081014. DOI:10.1515/znc-2001-11-1218

8. M. Gołebiowski, M. Cerkowniak, A. Urbanek, M. Dawgul, W. Kamysz, M. Bogus, P. Stepnowski, Microbiol Res. 2015, 170, 213-222. DOI:10.1016/j.micres.2014.06.004

9. E. N. Iornumbe, S. G. Yiase, R. Sha 'ato, T. A. Tor-Anyiin, IOSR J. Appl. Chem. 2015, 8, 7-15. DOI:10.9790/5736-08610715

10. S. Hadi, R. Mita, Nurhasanah, Modern Applied Science Journal 2009, 3, 12-17.

11. T. Yokoi, H. Kato, I. Y. Kim, K. Kikuta, M. Kawashita, C. Ohtsuki, Ceram. Int. 2012, 38, 3815-3820.

DOI:10.1016/j.ceramint.2012.01.030

12. A. Djeghri, F. Balegroune, A. Guehria-Laidoudi, T. Roisnel, J. Chem. Crystallogr. 2007, 37, 97-101.

DOI:10.1007/s10870-006-9154-9

13. D. Li, S. Yan, P. Proksch, Z. Liang, Q. Li, J. Xu, Afr. J. Biotechnol. 2013, 12, 3802-3806. DOI:10.5897/AJB2013.12417

14. G. Z. Papageorgiou, C. Panayiotou, Thermochim. Acta 2011, 523, 187-190. DOI:10.1016/j.tca.2011.05.023

15. Z. Cui, Z. Qiu, Polym. (United Kingdom). 2015, 67, 12-19. DOI:10.1016/j.polymer.2015.04.069

16. X. Shi, Z. Qiu, RSC Adv. 2015, 5, 79691-79698. DOI:10.1039/C5RA16801E

17. X. D. Zhang, S. K. Gillespie, J. M. Borrow, P. Hersey, Biochem. Pharmacol. 2003, 66, 1537-1545.

DOI:10.1016/S0006-2952(03)00509-4

18. K. Hiroyuki, T. Yoshihara, S. Sakamura, T. Shimanuki, T. Sato, A. Tajimi, Agric. Biol. Chem. 1989, 53, 2527-2528.
DOI:10.1080/00021369.1989.10869341

19. M. Watanabe. Y. Sakai, T. Teraoka. H. Abe, Y. Kono, J. Uzawa, K. Kobayashi, Y. Suzuki, A. Sakurai, Agric. Biol. Chem. 1990, 54, 1103-1104. DOI:10.1080/00021369.1990.10870045

20. Y. Suzuki, O. Kurita, Y. Kono, H. Hyakutake, A. Sakurai, Biosci. Biotechnol. Biochem. 1995, 59, 2049-2051.

DOI:10.1271/bbb.59.2049

21. Molinspiration Cheminformatics Software, http://www.molinspiration.com/cgi-bin/properties, (assessed: April 14, 2018).

22. C. A. Lipinski, F. Lombardo, B. W. Dominy, P. J. Feeney, $A d v$. Drug. Delivery Rev. 1997, 23, 4-25.

DOI:10.1016/S0169-409X(96)00423-1

23. D. F. Veber, S. R. Johnson, H. Y. Cheng, B. R. Smith, K. W. Ward, K. D. Kopple. J. Med. Chem. 2002, 45, 2615-2623. DOI:10.1021/jm020017n

24. P. Ertl, B. Rohde, P. Selzer, J. Med. Chem. 2000, 43, 3714-3717. DOI:10.1021/jm000942e

25 . Bioactivity data associative promiscuity pattern learning engine, http://pasilla.health.unm.edu/tomcat/badapple/badapple, (assessed: April 14, 2018).

26. ChEMBL. Compound Report card. The European Bioinformatics Institute (EMBL-EBI), https://www.ebi.ac.uk/chembl/ compound/inspect, (assessed: April 10, 2018).

27. B. A. Fowler (Ed.): Computational toxicology methods and applications for risk assessment. ICF International, Fairfax, VA, USA, 2013, p. 176.

28. O. Trott, A. J. Olson, J. Comput. Chem. 2010, 31, 455-461.

29. A. Siwek, P. Staczek, A. Strzelczyk, J. Stefanska, Lett. Drug Des. Discovery 2013, 10,2-10. DOI:10.2174/157018013804142393

30. R. Tang, L. Jin, C. Mou, J. Yin, S. Bai, D. Hu, J. Wu, S. Yang, B. Song, Chem. Cent. J. 2013, 7, 1-8.

DOI:10.1186/1752-153x-7-30

31. Protein Data Bank. Worldwide pdb, http://www.pdb.org, (assessed: April 12, 2018).

32. MarvinSketch version: 6.3.0, 2015, ChemAxon, http://www. chemaxon.com. (accessed: April 12, 2018).

33. J. Alvarez, B. Shoichet, PART V: Docking Strategies and Algorithms, Virtual Screening in Drug Discovery. CRC Press, Taylor \& Francis: Boca Raton, FL, 2005, pp. 301-348. DOI:10.1201/9781420028775

\section{Povzetek}

Protiglivno aktivnost monometil estra suberne kisline (monometil suberata) smo preučevali preko inhibicije rasti 11 različnih gliv in 3 oomicetnih sevov Phytophthora pomembnih v kmetijstvu. V primerjavi $\mathrm{z}$ referenčnim fungicidom himeksazolom, je monometil suberat izkazoval zmerno protiglivno aktivnost v koncentracijskem območju 100-300 $\mu \mathrm{g} / \mathrm{mL}$. Vrste Alternaria alternata, Fusarium equiseti, Fusarium fujikuroi in Phytophtora infestans GL-1 so bile najbolj občutljive, saj je povzročil tudi $100 \%$ inhibicijo rasti. Fizikalno-kemijski deskriptorji monometil suberata kažejo nizko toksičnost. Analiza molekularne umestitve, ki je vključevala sedem znanih protiglivnih tarčnih pozicij, je nakazala $\mathrm{N}$-miristoil transferazo kot najverjetnejše mesto interakcije. 